variant of the clinical spectrum caused by spontaneous dissection of the internal carotid artery in the neck. To date the symptoms and signs in five of the eight patients have regressed completely. We suggest that patients with this clinical presentation in whom the angiographic findings are compatible with a dissection should undergo exploration of the internal carotid artery and biopsy to establish the diagnosis. It is interesting that Tews ${ }^{10}$ in a retrospective survey of patients with this syndrome could identify 10 patients who had had a dissecting aneurysm of the internal carotid artery.

The authors are indebted to Dr R W Ross Russell, Dr I R Cameron, and Professor R Gilliatt for permission to study patients under their care.

\section{References}

${ }^{1}$ Marshall, J, The Management of Cerebrovascular Disease. London, Churchill, 1968.

2 Wolff, H, Headache and Other Head Pain. New York, Oxford University Press, 1963.

${ }^{3}$ Wells, C, Archives of Neurology, 1961, 5, 490.

${ }^{4}$ Brice, J G, and Crompton, M R, British Medical fournal, 1964, 3, 790.

${ }^{5}$ Northcroft, B G, and Morgan, A D, British fournal of Surgery, 1945, 32, 105.

${ }^{6}$ Crawford, T, fournal of Neurology, Neurosurgery, and Psychiatry, 1956, 19, 217.

'Thapedi, I M, Ashenhurst, E M, and Rozdilsky, B, Archives of Neurology, $1970,23,549$.

${ }^{8}$ Austin, M G, and Schaefer, R F, Archives of Pathology, 1957, 64, 205.

- Ojemann, R G, Fisher, C M, and Rich, J C, Stroke, 1972, 3, 434.

${ }^{10}$ Tews, J, 1975, personal communication.

\title{
Cromoglycate and other antiallergic drugs: a possible mechanism of action
}

\section{J C FOREMAN, L G GARLAND}

British Medical fournal, 1976, 1, 820-821

Cromoglycate represents one of the few new drugs to be introduced into clinical use this decade and several compounds are now emerging with similar activity (fig 1). Preliminary findings indicate that doxantrazole ${ }^{1}$ and $\mathrm{AH} 7725^{2}$ are effective by mouth in humans. As is often the case, new and useful drugs are in widespread use before there is any clear understanding of their mechanism of action and this is so with the antiallergic drugs. Our object is not to review all that is known about the pharmacology of cromoglycate, but to propose a hypothesis for the mechanism of action in terms of some new findings relating to the release of histamine and other mediators during immediatetype hypersensitivity reactions.

\section{Mechanism of mediator release}

Most manifestations of immediate-type hypersensitivity reactions appear to result from the release of mediators after the union of antigen with IgE antibody fixed to mast cell membranes. IgE antibody binds selectively to mast cells ${ }^{3}$ and basophil leucocytes, ${ }^{4}$ and when IgE combines with antigen a series of events takes place leading to the liberation of mediators such as histamine, serotonin, slow-reacting substance of anaphylaxis (SRS-A), prostaglandins, and putative mediators such as eosinophil chemotactic factor. ${ }^{5} 6$ The biochemical processes linking the antigen-antibody reaction on the cell membrane with the release of, for example, histamine-containing granules, is not full understood but it has been known for some years that calcium is required in the extracellular medium and that metabolic processes within the mast cell must be intact. ${ }^{7} 8$

In common with many other secretory systems, the antigeninduced secretion of histamine from mast cells requires calcium ions. Using a calcium ionophore (a substance which transports

\footnotetext{
Department of Pharmacology, University College London, London WC1E 6BT

J C FOREMAN, PHD, honorary research assistant

Pharmacology Laboratory, Wellcome Research Laboratories, Beckenham, Kent BR3 3BS

L G GARLAND, PHD, biochemical pharmacologist
}

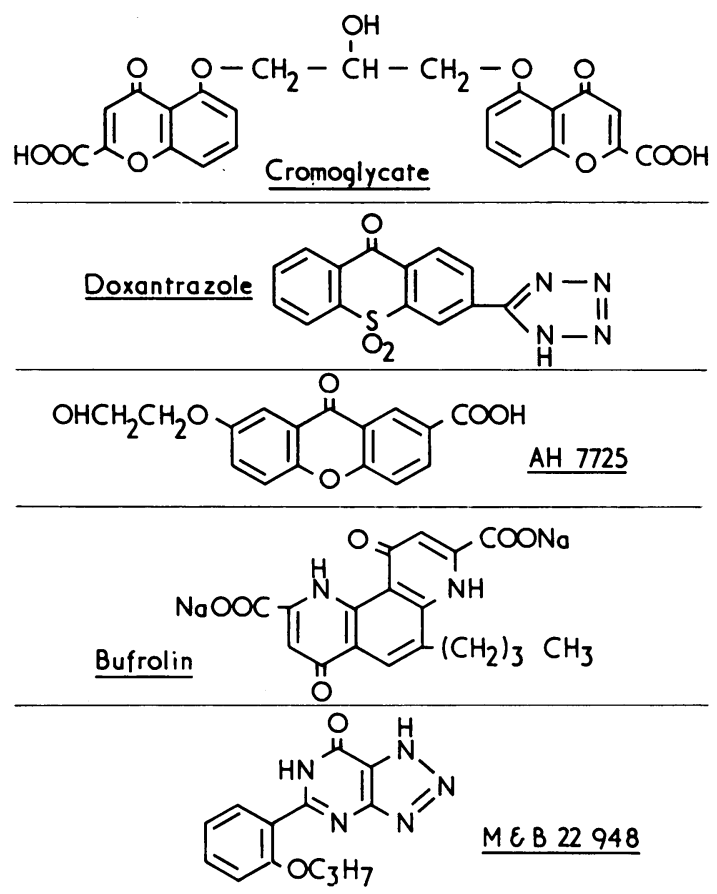

FIG 1-Structures of four new antiallergic drugs together with structure of cromoglycate for comparison.

calcium across biological membranes and other organic phases) Foreman et al have shown that the movement of calcium ions from the extracellular to the intracellular compartment of mast cells is sufficient to stimulate metabolically intact cells to secrete histamine. ${ }^{9}$ The primary event after union of antigen with mast cell-fixed antibody may therefore be an increase in the mast cell membrane permeability to calcium, which promotes entry of calcium into the cell. It is possible to show an increase in the association of 45 -calcium with mast cells after antigen stimulation. ${ }^{9} 10$

In addition to the requirement for calcium, histamine secretion does not proceed from antigen-stimulated cells if adenosine triphosphate (ATP) generation is blocked with inhibitors of oxidative phosphorylation and glycolysis. " ATP is utilised during the release of mediators and it appears that this ATP may be produced either by glycolysis or oxidative phosphorylation 
since both processes have to be blocked to abolish histamine secretion. The metabolic processes consuming ATP in mast cells are not known but almost certainly some is converted into cyclic $3^{\prime} 5^{\prime}$ adenosine monophosphate (cyclic AMP) by the enzyme adenyl cyclase while some may be required together with calcium to activate an actomyosin system responsible for granule extrusion.

Cyclic AMP (as the dibutyryl derivative) and agents which raise intracellular levels of cyclic AMP such as beta-adrenoceptor stimulants and phosphodiesterase inhibitors inhibit anaphylactic histamine and SRS-A release. ${ }^{12-14}$ Again, the mechanism by which cyclic AMP inhibits mediator release is not established but it may act by reducing mast cell membrane permeability to calcium. ${ }^{15}$

Fig 2 is a model for the biochemical mechanisms controlling histamine secretion incorporating the experimental data discussed in this section. It will serve as a basis for our hypothesis on the mechanism of action of antiallergic drugs.

\section{Site of action of antiallergic drugs}

There are numerous possible sites to be considered when investigating the action of drugs that inhibit immediate-type hypersensitivity reactions. The compounds shown in fig 1 have the following properties. ${ }^{16-20}$ Each inhibits anaphylactic reactions in passively sensitised tissues, and inhibition of antibody (IgE) synthesis is therefore unlikely to be the mechanism of action. Furthermore, none is a potent antagonist of the known mediators of immediate-type hypersensitivity such as histamine, serotonin, or SRS-A. Neither cromoglycate ${ }^{15}$ nor doxantrazole ${ }^{21}$ interferes with the antigen-antibody reaction itself and hence such antiallergic agents probably act on the biochemical events in the mast cell which follow the antigen-antibody reaction on the membrane. Indeed, each compound inhibits the release of histamine from isolated mast cells in vitro.

The calcium ionophore has been valuable in studies of the action of antiallergic agents. By providing an alternative route for calcium to enter into the mast cells, the ionophore bypasses the calcium-gating mechanism operated by the antigen-antibody reaction (fig 2). A drug which acts by inhibiting calcium transport through gates in the mast cell membrane opened by the antigenantibody reaction should not inhibit the calcium-transporting function of the ionophore. Thus drugs inhibiting histamine secretion by blocking antigen-induced calcium transport will not

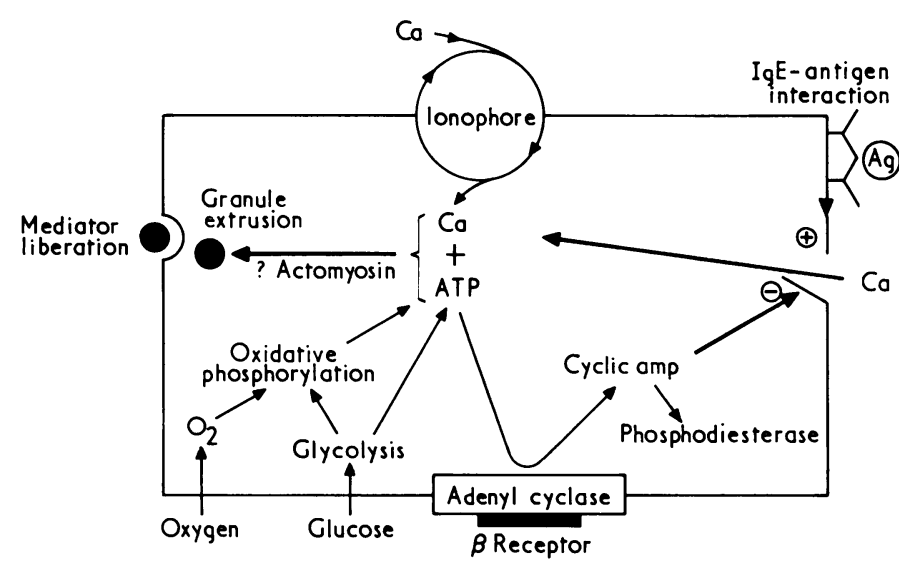

FIG 2-Model for mechanism of mediator release from mast cells and mode of action of antiallergic drugs. A mast cell is represented diagrammatically. IgE-antigen interaction opens calcium channels $(\oplus)$ in cell membrane, allowing calcium to enter cell and, together with ATP, cause extrusion of granules containing histamine and release of other mediators of immediatetype hypersensitivity such as SRS-A. Calcium entry is regulated by inhibitory action of CAMP $(\Theta)$ on calcium channels. Antiallergic drugs appear to act by reducing calcium transport into mast cell, possibly indirectly through inhibition of phosphodiesterase and a resultant increase in intracellular level of CAMP. inhibit ionophore-mediated calcium transport and histamine secretion, whereas drugs such as metabolic inhibitors which act after the entry of calcium into the cells (fig 2) will inhibit equally the release of histamine induced either by antigen or by ionophore. Although a preliminary study ${ }^{22}$ suggested that the ionophore-induced release of histamine from rat mast cells could be inhibited by cromoglycate, more extensive experiments $\stackrel{\Phi}{\Omega}$ were later carried out ${ }^{23}$ in which ionophore-induced histamine.. release and an anaphylactic-type histamine release were used in $\vec{\Rightarrow}$ parallel to differentiate the actions of several inhibitors. In the $\stackrel{9}{+}$ latter study, cromoglycate, doxantrazole, and bufrolin (ICI $\left.749^{917}\right)^{24}$ inhibited the anaphylactic-type reaction while the $\frac{\bar{F}}{\bar{N}}$ ionophore-induced release of histamine was unchanged. Thus each of these antiallergic drugs probably acts by blocking the antigen-induced transport of calcium.

The hypothesis is, then, that cromoglycate and at least two of $\vec{\nabla}$ the more recent antiallergic compounds (doxantrazole and bufrolin) inhibit antigen-induced mediator release by interfering $\vec{\omega}$ with calcium transport across the mast cell membrane, but more evidence is awaited from studies of antigen-induced 45 -calcium uptake into mast cells. The hypothesis may be extended by considering whether the prevention of the opening of the calcium gates by anti-allergic drugs is due to a direct or an indirect action. $\vec{\omega}$ There is evidence to suggest that compounds believed to raise $\dot{\infty}$ intracellular levels of cyclic AMP inhibit histamine release by $\mathcal{N}$ reducing calcium transport across the mast cell membrane 은 (fig 2)..$^{1523}$ Furthermore, both cromoglycate and doxantrazole $\omega$ inhibit the enzyme cyclic AMP-phosphodiesterase when tested $D$ in broken cell preparations. ${ }^{25}{ }^{26}$ Conceivably, therefore, these antiallergic drugs could act by raising intracellular levels of $\vec{\oplus}$ cyclic AMP, thus preventing calcium transport across the mast cell membrane. Examination of this hypothesis by direct measurement of the mast cell cyclic nucleotide levels after drug treatment is currently being performed. Some indirect support however, is provided by studies in which the antiallergic effects of cromoglycate ${ }^{27}$ and doxantrazole ${ }^{25}$ were augmented by the concomittant stimulation of adenyl cyclase with betaadrenoceptor stimulants.

\section{References}

${ }^{1}$ Haydn, S P, Bradley, J L, and Hughes, D T D, British Medical fournal, $1975,3,283$.

${ }^{2}$ Assem, E S K, Evans, J A, and McAllen, M, British Medical fournal 1974, 2, 93.

3 Ishizaka, T, et al, fournal of Immunology, 1969, 102, 884.

4 Tomioka, H, and Ishizaka, K, Fournal of Immunology, 1971, 107, 971.

5 Kay, A B, and Austen, K F, Fournal of Immunology, 1971, 107, 899.

6 Piper, P J, and Vane, J R, Nature, 1969, 223, 29.

${ }^{7}$ Mongar, J L, and Schild, H O, Fournal of Physiology, 1958, 140, 272.

8 Foreman, J C, and Mongar, J L, Fournal of Physiology, 1972, 224, 753

${ }^{9}$ Foreman, J C, Mongar, J L, and Gomperts, B D, Nature, 1973, 245, 249.

10 Foreman, J C, Hallett, M B, and Mongar, J L, British fournal of Pharma cology, 1975, 55, 283P.

${ }^{11}$ Diamant, B, International Archives of Allergy and Applied Immunology, $1975,49,155$.

12 Assem, E S K, and Schild, H O, Nature, 1969, 224, 1028.

13 Bourne, H R, Lichtenstein, L M, and Melmon, K L, fournal of Immunology, 1972, 108, 695.

14 Koopman, W J, Orange, R P, and Austen, K F, fournal of Immunology, 1970, 105, 1096.

15 Foreman, J C, et al, Biochemical Pharmacology, 1975, 24, 538.

${ }_{16} \mathrm{Cox}, \mathrm{J} \mathrm{S} \mathrm{G}$, et al, Advances in Drug Research, 1970, 5, 115.

${ }^{17}$ Batchelor, J F, et al, Lancet, 1975, 1, 1169.

18 Fullarton, J, Martin, L E, and Vardey, C, International Archives of Allergy and Applied Immunology, 1973, 45, 84.

${ }^{19}$ Evans, D P, and Thomson, D S, British fournal of Pharmacology, 1975, 53, 409.

${ }^{20}$ Broughton, B J, et al, Nature, 1974, 251, 650

21 Garland, L G, University of London PhD thesis, 1975.

22 Johnson, H G, and Bach, M K, fournal of Immunology, 1975, 114, 514. ${ }^{23}$ Garland, L G, and Mongar, J L, International Archives of Allergy and

24 Garland, L G, unpublished observations.

25 Follenfant, M J, et al, in Proceedings VI Congress of Pharmacology, p 360. Helsinki, Finnish Pharmacological Society, 1975.

${ }^{26}$ Roy, A C, and Warren, B T, Biochemical Pharmacology, 1974, 23, 917.

27 Taylor, W A, et al, International Archives of Allergy and Applied Immunology, 1974, 46, 104. 